A. Shyshatskyi ${ }^{1}$, S. Suhak ${ }^{2}$, M. Tiurnikov ${ }^{2}$, A. Lyashenko ${ }^{3}$, T. Bokhno ${ }^{3}$, O. Bondar ${ }^{4}$, A. Melnyk ${ }^{5}$

${ }^{1}$ Central Research Institute of Weapons and Military Equipment of Armed Forces of Ukraine, Kyiv, Ukraine

${ }^{2}$ Military unit A0106, Kyiv, Ukraine

${ }^{3}$ Military institute of telecommunications and information named after Heroes of Krut, Kyiv, Ukraine

${ }^{4}$ Military unit A0224, Mykolaiv, Ukraine

${ }^{5}$ Communication center of State Special Communications Service of Ukraine, Odessa, Ukraine

\title{
METHOD OF ASSESSMENT OF THE EFFICIENCY OF THE COMMUNICATION OF OPERATIONAL TROOP GROUPING SYSTEM
}

\begin{abstract}
The most distinctive features of military communications systems are the high degree of a priori uncertainty about the operational situation and the small amount of source data for communications planning. In such circumstances, it is important to make the right decision-making appraisal apparatus, which will allow the officials of the system management bodies to be confident in the decisions made. Deciding to build a communications system at any level usually involves defining the purpose of its operation, selecting metrics and justifying the evaluation criteria, synthesizing alternative structures, and finding a rational option for deploying the communications system. The practice of the troops has convincingly shown that in the theory and practice of communications, there is a need to improve the scientific and methodological apparatus, which will meet the current conditions of operation of control systems and provide a more adequate assessment of the effectiveness of deployable communications systems. In this article, the authors propose a method for evaluating the effectiveness of the communication system of the operational troop grouping. The above method is based on the first time use of the communication system accessibility indicator. In the course of this research, the authors used the basic principles of communication theory, noise immunity theory and intelligence. The novelty of the proposed method is that the communication system operational troops grouping are estimated by generalized indicator of availability of channel resources and network communications system of the operational troops grouping. The practical value of the proposed methodology is that the methodology allows for a more accurate assessment of the communications system, the identification of deployment arrangements and measures to improve the effectiveness of the operational troops grouping.
\end{abstract}

Keywords : communication system evaluation; effectiveness, noise immunity; intelligence; operational troop grouping.

\section{Introduction}

The most distinctive features of military communications systems are the high degree of a priori uncertainty about the operational situation and the small amount of source data for communications planning.

In such circumstances, it is important to make the right decision-making appraisal apparatus, which will allow the officials of the system management bodies to be confident in the decisions made.

Deciding to build a communications system at any level usually involves defining the purpose of its operation, selecting metrics and justifying the evaluation criteria, synthesizing alternative structures, and finding a rational option for deploying the communications system.

The practice of the troops has convincingly shown that in the theory and practice of communications, there is a need to improve the scientific and methodological apparatus, which will meet the current conditions of operation of control systems and provide a more adequate assessment of the effectiveness of deployable communications systems.

One of the main areas of their improvement and development is the use of a new approach to determine the performance indicators and criteria that meet the current conditions and factors of combat (the purpose of the operation), as well as the requirements imposed on the communication system by the management system.

According to this approach, the effectiveness of the communication system is one of the indicators of its role and purpose. Despite the fact that the communication system does not directly influence the execution of the tasks and causing the enemy maximum losses, its role in achieving the goal of the battle (operation) is enormous. To define this role, the concept of the effectiveness of the communication system is introduced, which means the degree of realization of its possibilities for information exchange in specific conditions of the environment [1-5].

Therefore, the purpose of the article is to develop a method of assessment of the efficiency of the communication of operational troop grouping system.

\section{Presentation of the main material}

The calculation of performance indicators is directly related to the determination of the results of the evaluated solution. There are two options:

the first is related to the experimental validation of the recommendations and therefore the determination of the result is limited to evaluation;

the second arises in the priori evaluation of efficiency when the result is not yet available, but it should be predicted, as a result of which the results of the decision are determined by forecasting methods $[5,6]$.

The first case is the most important for theory, and the second for practice, since performance evaluation must be the first to make a decision and determine its value.

With regard to the operational troops grouping (OTG) communication system, its effectiveness must be evaluated on the basis of its characteristics.

Since the communication system has many properties, the list of indicators that should be used to 
evaluate the quality of the communication system should be limited.

In practice, this means that the quality assessment should not be based on all but the most important indicators that determine the basic aspects of the performance of the communication system or its individual elements. This approach allows you to focus on the key metrics of the communication system that enable it to best address its core challenge in predictable operating conditions. Therefore, a comprehensive and objective evaluation of the effectiveness of the communication system can be carried out using a system of indicators and criteria, including the main and additional indicators on the basic and partial properties, respectively $[1,5,10]$.

As a basic feature, given its special importance for the operational grouping of troops [10], it is proposed to accept the accessibility of the communication system and to obtain its dependence on other partial indicators. Since accessibility characterizes the ability of a military communications system to obtain the management resources (operational composition) of the necessary communications resources (its types, services, services), it seems that the accessibility indicator, on the one hand, should reflect the spatial aspect, on the other hand - take into account the ultimate object stability of the elements of the communication system in conditions of complex influence of the enemy.

The spatial aspect refers to such an objective (spatial and topological) position of the control system users regarding the elements of the communication system when they are always able to use the channel resource created by it, having at its disposal regular and added means of communication [3, 4].

These particularities of generating a generic accessibility indicator, arising from the fact that they are of fundamental importance to the OTG communication system, must be reflected in the corresponding advanced methodology for evaluating the effectiveness of the OTG communication system.

However, it should be understood that the accessibility of the communication system depends primarily on the structure and location of its elements in the operating space, the location of users, length of access lines, physical and geographical conditions of the terrain, availability of forces and devices of communication [1]. That is why the improved methodology for evaluating the availability of the communication system used the probability of user access to the communication system resource on the first attempt, calculated on the functionality $[1,2]$

$$
P^{a v}=a\left(D, P_{i}^{a v}\right) \text {. }
$$

This figure depends on the number of elements of the communication system that are potentially capable of providing users with a channel resource and can be used by them from the areas of their dislocation using the available communication devices (ie, the numerical value of the components of the accessibility vector $D$ ) and their object stability $P_{i}^{a v}$. In this case, the multiplicity of access $i$ (the ability to provide the user with one, two or more independent routes of information transmission) suggests a higher probability of access to the channel resource on the first attempt.

Since the OTG operational space requires a solid coverage of the communication, the spatial accessibility indicator should reflect the principle of "territorial" orientation of the communication system. In this approach, spatial accessibility is most appropriate to be estimated by a vector $D=\left\{d_{l}\right\}$ whose components have some scalar value $d_{l}$. The content of the scalar value $d_{l}=0 \ldots 1$ is that from the $d_{l}$-th part of the area of the operating space, the network of OTG radio access, consisting of $L$ elements, is able to provide any user with the potential to obtain the necessary part of the channel resource of the communication system through $l$ independent routes:

$$
D=\left\{d_{1}, d_{2}, d_{3}, \ldots, d_{l}, \ldots, d_{L}\right\}, l=\overline{1, L},
$$

where $L$ is the total number of elements of the communication system that are deployed to provide users with a channel resource.

When

$$
L=\sum_{k=1}^{m} n_{k},
$$

where $m$ is the number of levels in the communication system; $n_{k}$ is the number of elements in the $k$-th echelon (levels).

Hereafter, below the echelons, we will understand the range of antenna lifting heights of radio access stations and relay transmitters.

To determine in (2) the component of vector $D$, it is necessary to find the ratio of the area from which the user (subscriber) is able to access the elements of the communication system to the entire area of the OTG defense band. Then

$$
d_{l}=\frac{S_{l}}{S_{\text {tot }}},
$$

where $S_{l}$ is the area of the radio access zone from $l$ elements of the communication system; $S_{t o t}$ is the total area of OTG operating space.

Because spatial accessibility is characterized by component values $\left\{d_{l_{\min }}\right\}$ of the availability vector $D$, their relationship can be represented as a spatial accessibility factor $K_{\text {spat. } a v}$. Then

$$
K_{\text {spat.av }}=\frac{S_{l}}{S_{\text {tot }}} \text { if } l=l_{\min } .
$$

By its nature, the radio access network is zonal. Coverage areas are part of the territory (operating space lanes) that are connected to one of the elements of the radio access network, as well as their intersection zones. The sizes of these zones depend on the tactical and technical characteristics of the radio facilities, the heights of raising their antennas, the operating frequency, the interference situation and other factors 
affecting the quality of the provided radio communication [6-10].

The original product of the proposed sequence of calculations of the availability index of the OTG communication system is a matrix $A(i)$ that has a look $M \times N$ (where $M$ and $N$ are the number of the $d_{l}$-th parts of the area along the front and into the depth of the operating space, respectively), the elements of which $a_{m n}(i)$ represent a single area on an electronic map scale. As a result of calculations for the $i$-th element of the communication system, the elements of the matrix take on values $a_{m n}(i)=1$ in case the user can access from the $a_{m n}$-th plots of the area to the $i$-th system element or $a_{m n}(i)=0$ otherwise [10].

The use of digital terrain information in calculating the availability of a communication system resource allows us to determine more accurately than before the actual area of coverage of each element of the communication system $S_{i}$ according to the expression

$$
S_{i}=\sum_{m=1}^{M} \sum_{n=1}^{N} \alpha_{m n}(i),
$$

where $M \times N=S_{\text {tot }}$ is the total (covered) area of operating space.

Knowing that the structure of the communication system consists of $L$ of elements in different relationships, you can calculate the vector of availability $D$ for the whole system as a whole. You need to have this $L$ matrices $A(i)$ for each $i$-th element separately coating $S_{i}$, which determine essentially the area for each element of the communication system. Then the area of the intersection is no less than that $l$ of its elements $S_{i}$ is suggested to calculate by the formula

$$
S_{l}=\bigcup_{i=1}^{C_{L}^{l}}\left(\bigcap_{12} \ldots \bigcap_{l} S_{i}\right),(i=\overline{1, L} ; l=\overline{1, L}),
$$

where $C_{L}^{l}$ is the number of combinations from $L$ to $l$ of potentially reflective quantities overlapping area $l$, which may be created in the operating area of a future operation [11].

Thus, by determining the values of the quantities of the set $\left\{S_{l}\right\}$, it is possible to find, in accordance with expressions (2) and (4), the values of all components of the accessibility vector $D$. For calculations, while estimating the accessibility index and vector $D$, it is proposed to use the following approach to its calculation.

The output data for the calculations are the number of $L$ elements of the communication system of the corresponding structure $G$; the maximum number of $M$ rows of matrices $A$; the maximum number of $N$ columns of matrices $A$; many matrices $\{A\}$, the elements of which are calculated according to expression (6), summarized in a three-dimensional array of data $A[1 \ldots M, 1 \ldots N, 1 \ldots L]$.
You must have a variable $S$ to store intermediate and output data, the multiplicity counter $k$ and the onedimensional array $S[1 \ldots k][5,10]$.

After inputting the total area of the operating area is determined and the array of input data is zeroed. The same elements of all matrices are then checked for access. In the case of a satisfactory answer, the value of the multiplicity counter and the corresponding value of the array $S_{k}$ are changed.

After the verification of all elements, calculations are made of the ratio of the area to the frequency of access to the total area and the output of the obtained results. The initial data show which part of the area of the operating area (covered or served relative to the territory) is able to access $l$ elements of the communication network, ie, the creation of $l$ independent routes [5-10].

Thus, the values of the components of the accessibility vector allow us to conclude how the analyzed (planned) variant of the construction of the communication system will provide users access to its channel resource. However, the values of the accessibility vector components obtained alone are not sufficient to uniquely determine the required number of independent access routes. In the face of complex adversary action, you need to have information about the projected object stability of the communications elements that provide access.

If their stability $P_{s t i}$ was ideal $\left(P_{s t i}=1, i=1, L\right)$, then for each of the users, guaranteed reliable access to one element of the communication system would be sufficient for guaranteed access to the channel resource. Otherwise, a well-founded question arises as to how much of a planned communication system it is necessary to create independent routes to ensure its necessary stability.

This question can be solved in this way $[6,10,11]$. Let the user, while in a certain location of the operating space, be able to expand the $l$ communication lines available to him in accordance with the $l$ elements of the communication system.

Also known are the values of the object stability of its elements $\left\{P_{s t i}\right\}$. For ease of calculation, it is assumed that all elements of the communication system providing access to users are equal to $\left\{P_{s t i}\right\}=P_{i}^{a v}$. Then the probability of an occurring event $P_{n e s}^{a v}$, the user of which will gain access to the link resource of the communication system, can be found from the expression [11]:

$$
P_{n e s}^{a v}=1-\prod_{i=1}^{l}\left(1-P_{i}^{a v}\right)
$$

By determining the value $P_{i}^{a v}$ and demanding the value of the indicator $P_{n e s}^{a v}$, you can find the minimum required number $l_{\min }$ of elements of the communication system to which the user must be provided access: 


$$
l_{\min }=\log _{\left(1-P^{a v}\right)}\left[1-P_{n e s}^{a v}\right] .
$$

Determining the minimum level of number of independent routes for the user in the specific conditions of the enemy's influence, corresponding to the requirements on the stability of the communication system, the values of the components of the accessibility vector (4) are estimated and the reasoned conclusion about the sufficiency or insufficiency of the values of this structural characteristic for a particular variant of the implementation of the communication system is made. In contrast to the known methods [1-3, 5-7], the object stability of the access elements is taken into account in the calculations of the spatial accessibility of the communication system.

Based on the requirements of the management system, each user, along with the possibility of spatial access, should be provided with the necessary (sufficient) resource capacity of the communication system, which, as a rule, for the analog version of its practical implementation is quantified in the communication channels, and for digital is the bit rate (bit/s). Thus,

$$
A_{i}=\min \left(B_{\text {anc }} ; C_{\text {radio }} ; Z_{\text {sec }}\right),
$$

where $B_{a n c}$ is the channel capacity of the anchor lines; $C_{\text {radio }}$ is the number of radio access channels; $Z_{\text {sec }}$ is the availability of secrecy equipment.

For the purpose of determining the availability of a communication system, which characterizes its capabilities in providing users with the required channel resource, which reflects the content of the bandwidth, the coefficient of availability on the bandwidth can be used for analog transmission systems (ATS)

$$
K_{\text {av band }}^{A T S}=\min \left\{\frac{A_{i}}{A_{\text {nes }}}, 1\right\},
$$

where $A_{\text {nes }}$ is the required number of communication channels. To determine the availability of a communication system using a digital transmission system (DTS), it is advisable to enter a bandwidth availability factor in the form

$$
K_{a v}^{D T S}=\min \left\{\frac{V_{\text {plan }}}{V_{\text {nes }}}, 1\right\},
$$

where $V_{\text {plan }}$ is the planned (implemented) transmission speed; $V_{\text {nes }}$ is the required transmission speed.

If the value is bigger than 1 , then the reserve of information resources of the network is calculated by using the following expression:

$$
Q_{\text {res }}=K_{\text {av band }}-1 \text {. }
$$

Because the coefficients calculated using expressions (5), (11), (12) reflect the physical content of the spatial (in terms of coverage) and channel (in terms of capacity) types of accessibility, the requirements have to be met together, it makes sense to enter a generic indicator of the communication system

$$
K_{C S}=\min \left\{K_{\text {av band }} ; K_{\text {spat. av }}\right\} \text {. }
$$

In order to increase the validity of the adopted decision on the choice of the structure of the communication system in accordance with the requirement for the information exchange, and therefore access to it by the officials of the control bodies, the criteria values of the generalized indicator (13) should be set in accordance with the degree of satisfaction of the needs of the bandwidth control system as the main indicator of effectiveness, reflecting the most essential feature of the military communication system.

The structure of the proposed method of assessment of the efficiency of the communication of operational troop grouping system is presented in Fig. 1.

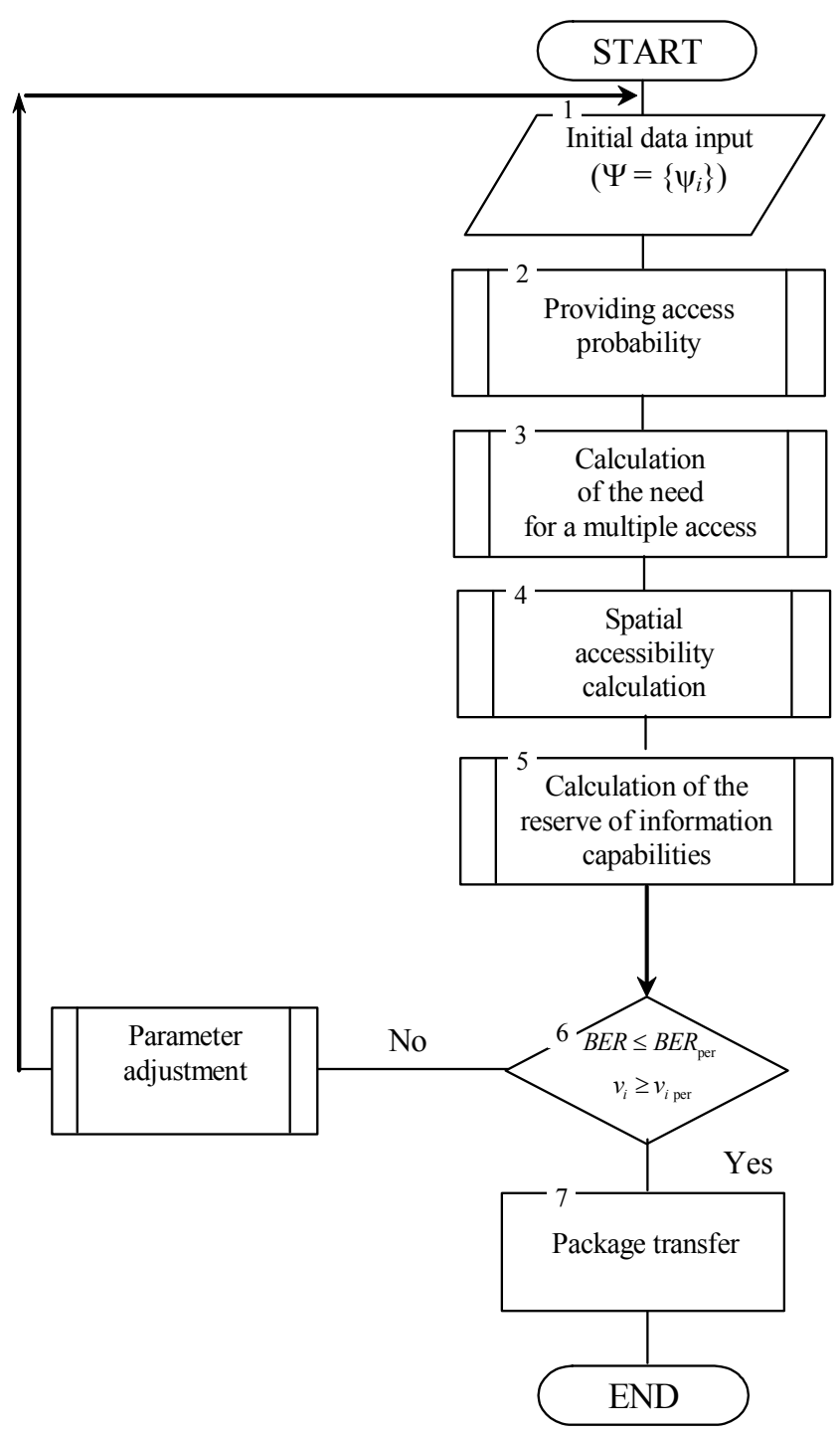

Fig. 1. Methodology for evaluating the effectiveness of the communication system

The proposed approach to the evaluation of the effectiveness of the communication system is advantageous and obviously different from the known ones [1-9].

Thus, the methods used to evaluate the effectiveness of the communication system at this time 
reflect, as a rule, one or more of its partial properties, such as security $[1,5]$, stability (in the aspect of structural survivability) [6, 8] or throughput [2, 7], which, from the point of view of the systematic approach, is insufficient, since the individual properties, even if significant, but considered separately, do not reflect their mutual influence on each other.

For this reason, the evaluation of the effectiveness of the communication system is formally versatile but not complex. In an improved methodology, the accessibility indicator binds to the basic throughput and integral stability index, which includes partial indicators of survivability, noise immunity and reliability, which allows a comprehensive evaluation of the OTG communication system, and therefore, to make a more reasonable decision on its building.

\section{Conclusions}

1. The identified contradictions between the needs of the management system and the capabilities of the communication system, as well as the differences in the estimates of its predicted and real efficiency in the main indicators can be resolved:
Organizationally can be resolved on the basis of the application of the principle of systematic, justification and implementation of a new territorially distributed structure, including the radio access network;

technically can be resolved by digitizing the communication system and translating it into a higherquality technological platform with the predominant use of domestic communication means;

methodologically can be resolved by improving the methodology for evaluating its effectiveness and developing scientifically sound recommendations for the practical implementation and formation of the structure of a communications system that meets the modern and promising requirements of commanding troops.

2. Also, it is necessary to look not for an optimal solution, but for a rational solution between the required efficiency and the acceptable cost.

The direction of further research should be considered the development of methodological bases for the operational management of military radio communication facilities.

\section{REFERENCES}

1. Shyshatskiy, A.V., Bashkirov, O.M. and Kostina, O.M (2015), "Development of integrated systems and data for Armed Forces", Arms and military equipment, No 1(5), pp. 35-40.

2. Korneyko, O.V., Kuvshinov, O.V. and Lezhniuk, O.P. (2010), The basics of the theory of telecomunication, Kyiv, $786 \mathrm{p}$.

3. Varakin, L.E. (1970), Theory of complex signals, Radio, Mocsow, 304 p.

4. Sklyar, B. (2007), Digital communication. Theoretical foundations and practical application, Williams, Moscow, 1104 p.

5. Zhuk, O.G., Shyshatskiy, A.V., Zhuk, P.V. and Zhyvotovskyi, R.M. (2017), "Methodological substances of management of the radio-resource managing systems of military radio communication", Information Processing Systems, Vol. 5 (151), pp. 16-25, DOI: https://doi.org/10.30748/soi.2017.151.02

6. Shyshatskyi, A.V., Olshanskyi, V.V. and Zhyvotovskyi, R.M. (2016), "Algorithm of the choosing working frequencies for facilities of military radio communication in the conditions of intentional interference", Systems of armament and military equipment, No. 2, pp. 62-66.

7. Romanenko, I.O., Shyshatskyi, A.V., Zhyvotovskyi, R.M. and Petruk, S.M. (2017), "The concept of the organization of interaction of elements of military radio communication systems", Science and Technology of the Air Force of the Armed Forces of Ukraine. No 1, pp. 97-100.

8. Sova O.Ya., Romanuk, V.A. Zuk, P.V. and Umanec, Ya.L. (2012), "Synthesis methodology of smart nodes management systems of perspective mobile radio networks with dynamic topology", Collection of scientific works of HUPS, No 3. pp. 51-60.

9. Sova, O.Ya., Minochkin, D.A., Romanyuk, V.A. and Zhuk, P.V. (2015), "Model of organization of information resources of intelligent management systems of nodes of mobile radio networks of the class MANET", Science and Technology of the Air Force of the Armed Forces of Ukraine, No. 2(19). pp. 51-57.

10. Golubtsov, S.G. and Leonovich G.A. (2009), "Methodology for assessing the effectiveness of the functioning of the field backbone communication network of an association by a comprehensive accessibility indicator", Science and military security, No. 3. pp. 23-29.

\section{Відомості пРо АвтоPIB / AвоUT тHE AUTHORS}

Шишацький Андрій Володимирович - кандидат технічних наук, начальник науково-дослідної лабораторії, Центральний науково-дослідний інститут озброєння та військової техніки Збройних Сил України, Київ, Україна; Andrii Shyshatskyi - Candidate of Technical Sciences, Associate Professor, Head of the science-research laboratories, Central Research Institute of Weapons and Military Equipment of Armed Forces of Ukraine, Kyiv, Ukraine; e-mail ierikon12@gmail.com; ORCID ID: http://orcid.org/0000-0001-6731-6390.

Тюрніков Михайло Миколайович - старший офіцер, Військова частина А0106, Київ, Україна; Mykhailo Tiurnikov - competitor, Military unit A0106, Kyiv, Ukraine; e-mail: na4grup@ukr.net; ORCID ID: http://orcid.org/0000-0002-6291-9819.

Сугак Сергій Олександрович - старший офіцер, Військова частина А0106, Київ, Україна; Serhii Suhak - competitor, Military unit A0106, Kyiv, Ukraine; e-mail: sugak_01@ukr.net; ORCID ID: http://orcid.org/0000-0003-4687-323X. 
Бондар Олексій Петрович - начальник відділу, Військова частина А0224, Миколаїв, Україна;

Oleksii Bondar - Head of Department, Military unit A0224, Mykolaiv, Ukraine;

e-mail: phoenix791981@ukr.net; ORCID ID: http://orcid.org/0000-0002-5658-1495.

Мельник Артур Олександрович - начальник вузла, Вузол зв'язку Державної служби Спеціального зв'язку та захисту інформації України, Одеса, Україна;

Artur Melnyk - Head of the node, State Service of Special Communication and Information Protection Service of Ukraine, Odessa, Ukraine; e-mail: Shooter3101@gmail.com; ORCID ID: http://orcid.org/0000-0001-9215-889X.

Бохно Тарас Романович - начальник редакційно-видавничого відділу, Військовий інститут телекомунікацій та інформатизації імені Героїв Крут, Київ, Україна;

Taras Bokhno - Head of the editorial and publishing department, Military institute of telecommunications and informatization named after Heroes of Kruty, Kyiv, Ukraine; e-mail: Taras Bokhno@ukr.net; ORCID ID: https://orcid.org/0000-0002-7033-8723.

Ляшенко Ганна Тарасівна - науковий співробітник науково-дослідного відділу, Військовий інститут телекомунікацій та інформатизації імені Героїв Крут, Київ, Україна;

Anna Lyashenko - Research Associate, Military institute of telecommunications and informatization named after Heroes of Kruty, Kyiv, Ukraine;

e-mail: Anutka-2-0-0-8@ukr.net; ORCID ID: https://orcid.org/0000-0002-5318-8663.

\section{Методика оцінки ефективності системи зв'язку оперативного угруповання військ}

А. В. Шишацький, С. О. Сугак, М. М. Тюрніков, Г. Т. Ляшенко, Т. Р. Бохно, О. П. Бондар, А. О. Мельник

Анотац ія. Найбільш характерними особливостями побудови систем зв'язку військового призначення є високий ступінь апріорної невизначеності стосовно оперативної обстановки та малий обсяг вихідних даних для планування зв'язку. У таких умовах важливий правильний вибір апарату оцінки прийнятих управлінських рішень, який дозволить посадовим особам органів управління системою зв'язку бути впевненим у рішеннях, що приймаються. Прийняття рішення на побудову системи зв’язку будь-якого рівня, як правило, включає визначення мети іії функціонування, вибір показників і обгрунтування критеріїв оцінки, синтез альтернативних структур і пошук раціонального варіанту розгортання системи зв'язку. Практика військ переконливо показала, що в теорії та практиці організації зв'язку виникла необхідність в удосконаленні науково-методичного апарату, що буде відповідати сучасним умовам функціонування систем управління та забезпечувати більш адекватну оцінку ефективності систем зв'язку, що розгортаються. В зазначеній статті авторами запропоновано методику оцінки ефективності системи зв'язку оперативного угруповання військ. Зазначена методика заснована на використання показника доступності системи зв'язку з першого разу. В ході зазначеного дослідження авторами використані основні положення теорії зв'язку, теорії завадостійкості та розвідзахищеності. Новизна запропонованої методики полягає в тому, що система зв'язку оперативного угруповання військ оцінюється по узагальненому показнику доступності канальних та мережевих ресурсів системи зв'язку оперативного угруповання військ. Практичне значення запропонованої методики полягає в тому, що зазначена методика дозволяє більш точніше оцінити систему зв'язку, визначити заходи щодо розгортання системи зв'язку та виробити заходи стосовно підвищення ефективності системи зв'язку оперативного угруповання військ.

Ключ ов і слов а : оцінювання системи зв'язку; ефективність; завадозахищеність; розвідзахищеність; оперативне угруповання військ.

\section{Методика оценки эффективности системы связи оперативной группировки войск}

А. В. Шишацкий, С. А. Сугак, М. Н. Тюрников, А. Т. Ляшенко, Т. Р. Бохно, А. П. Бондарь, А. А. Мельник

Аннотация. Наиболее характерными особенностями построения систем связи военного назначения является высокая степень априорной неопределенности относительно оперативной обстановки и малый объем исходных данных для планирования связи. В таких условиях важен правильный выбор аппарата оценки принимаемых управленческих решений, который позволит должностным лицам органов управления системой связи быть уверенным в решениях, которые принимаются. Принятие решения на построение системы связи любого уровня, как правило, включает определение цели ее функционирования, выбор показателей и обоснование критериев оценки, синтез альтернативных структур и поиск рационального варианта развертывания системы связи. Практика войск убедительно показала, что в теории и практике организации связи возникла необходимость в совершенствовании научно-методического аппарата, который будет соответствовать современным условиям функционирования систем управления и обеспечивать более адекватную оценку эффективности систем связи, разворачиваются. В указанной статье авторами предложена методика оценки эффективности системы связи оперативной группировки войск. Указанная методика основана на использование показателя доступности системы связи с первого раза. В ходе указанного исследования авторами использованы основные положения теории связи, теории помехоустойчивости и развезащищённости. Новизна предложенной методики заключается в том, что система связи оперативной группировки войск оценивается по обобщенному показателю доступности канальных и сетевых ресурсов системы связи оперативной группировки войск. Практическое значение предложенной методики заключается в том, что указанная методика позволяет более точно оценить систему связи, определить меры по развертыванию системы связи и выработать меры по повышению эффективности системы связи оперативной группировки войск.

Ключевые слова: оценка системы связи; эффективность; помехозащищенность; разведзащищённость; оперативная группировка войск. 